Jurnal Konstruksi Hukum | ISSN: 2746-5055

Vol. 2, No. 1, Januari 2021 Hal. 62-67 | Tersedia online di https://www.ejournal.warmadewa.ac.id/index.php/jukonhum

DOI: https://10.22225/jkh.2.1.2969.62-67

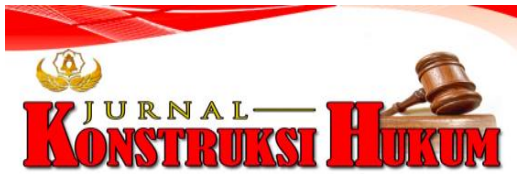

\title{
PELAKSANAAN PERATURAN DAERAH TATA RUANG KABUPATEN GIANYAR TERHADAP PEMBANGUNAN FASILITAS PARIWISATA SEMPADAN SUNGAI AYUNG
}

\author{
I Kadek Darmayasa, I Putu Gede Seputra, Luh Putu Suryani Jurusan \\ FakuItas Hukum Universitas Warmadewa, Denpasar-Bali, Indonesia
}

\begin{abstract}
Abstrak
MenangguIangi dampak negatif terhadap Iingkungan dan guna menciptakan tata ruang yang baik. Kabupaten Gianya melakukan pengendaIian pemanfaatan ruang meIaIui tata ruang penepatan zonasi, perizinan, pemberian intensif dan disintensif. Penelitian ini bertujuan untuk menganalisis pengaturan pembangunan fasilitas pariwisata sempadan sungai dan mengetahui Pelaksanaan Peraturan Daerah Nomor 16 Tahun 2012 Tentang Rencana Tata Ruang Wilayah Kabupaten Gianyar dalam pembangunan fasilitas pariwisata. Metode penelitian yang digunakan adalah penelitian hukum Empiris. Penelitian ini memilih lokasi di Banjar Kedewatan Anyar, Desa kedewatan, Kecamatan Ubud, Kabupaten Gianyar. Hasil analisis menunjukan bahwa pengaturan pembangunan fasilitas pariwisata sempadan sungai dalam hukum positif di Indonesia termuat dalam UndangUndang Nomor 26 tahun 2007 Tentang Perencanaan Ruang. Selain dalam Undang-Undang tersebut sempadan sungai juga di atur dalam Peraturan Pemerintah Nomor 26 Tahun 2008 Tentang Rencana Tata Ruang Wilayah Nasional. Demi adanya keselarasan terhadap Perundang-Undangan yang sudah ada, maka Daerah Kabupaten Gianyar juga membuat Peraturan Daerah Kabupaten Gianyar Nomor 16 tahun 2012 tentang Rencana Tata Ruang Wilayah tahun 2012-2032 mengatur tentang sempadan sungai pada Pasal 37 Ayat 2 menjelaskan mengenai pembangunan yang dilakukan di dekat Kawasan sungai yang telah diberikan aturan pembangunan di sungai pedesaan. Dari Pelaksanaan Peraturan Daerah Nomor 16 Tahun 2012 Tentang Rencana Tata Ruang Wilayah Kabupaten Gianyar dalam pembangunan fasilitas pariwisata sudah berjalan dengan baik tetapi dapat dilihat melalui kalkulasi yang dihitung oleh Kapala Bidang Penataan Ruang bahwa telah terlaksana sebesar 89\% sudah berjalan dengan baik dan $11 \%$ masih adanya penyimpangan.
\end{abstract}

Kata Kunci: Pelaksanaan, Tata Ruang, Sungai Ayung

\begin{abstract}
Disrupt. Reduce negative impacts on the environment and to create good spatial planning. Gianya Regency carries out spatial use control through zoning, licensing, intensive and disintensive spatial planning. This study aims to analyze the arrangements for the development of river border tourism facilities and to find out the implementation of Regional Regulation Number 16 of 2012 concerning the Gianyar Regency Spatial Plan in the construction of tourism facilities. The research method used is empirical legal research. This study chose a location in Banjar Kedewatan Anyar, Kedewatan Village, Ubud District, Gianyar Regency. The results of the analysis show that the regulation of river border tourism facility development in positive law in Indonesia is contained in Law Number 26 of 2007 concerning Spatial Planning. Apart from this Law, river borders are also regulated in Government Regulation Number 26 of 2008 concerning National Spatial Planning. For the sake of harmony with the existing legislation, the Gianyar Regency Region has also made the Gianyar Regency Regional Regulation Number 16 of 2012 concerning the 2012-2032 Regional Spatial Plan which regulates river boundaries in Article 37 Paragraph 2 describes development carried out near River areas that have been given development rules in rural rivers. From the Implementation of Regional Regulation Number 16 of 2012 concerning the Regional Spatial Plan of Gianyar Regency in the construction of tourism facilities it has been going well but it can be seen through calculations calculated by the Head of the Spatial Planning Division that $89 \%$ has been implemented well and $11 \%$ is still there a deviation.
\end{abstract}

Keywords: Implementation, Spatial Planning, Ayung River

\section{PENDAHULUAN}

Negara Indonesia $70 \%$ merupakan wilayah perairan yang terdiri atas wilayah laut, danau dan sungai. Keadaan geografis Indonesia yang didominasi oleh wilayah perairan ini mewajibkan pemerintah untuk membuat kebijakan penataan ruang dengan baik. Undang-undang Republik Indonesia Nomor 26 Tahun 2007 Tentang Penataan Ruang bahwa ruang wilayah Indonesia yang merupakan negara 
kepulauan berciri Nusantara, baik sebagai kesatuan wadah yang meliputi ruang darat, ruang laut, dan ruang udara, termasuk ruang di dalam bumi, maupun sebagai sumber daya, Tujuan dari adanya penataan ruang yang baik adalah untuk mewujudkan keterpaduan antara ruang udara, ruang darat, dan ruang laut. Sebagai destinasi wisata perairan di Pulau Bali tidak hanya menyediakan keindahan pantai untuk dapat dinikmati oleh wisatawan domestic maupun mancanegara, namun terdapat juga wilayah sungai yang dapat dimanfaatkan dan dinikmati oleh masyarakat dan wisatawan yang berkunjung ke Pulau Bali.

Pulau Bali memiliki aturan yang mengatur mengenai tata ruang yang diatur dalam Peraturan Daerah Provinsi Bali Nomor 16 Tahun 2009 Tentang Rencana Tata Ruang Wilayah Provinsi Bali Tahun 2009-2029. Jika diperhatikan melalui hakekat Rencana Tata Ruang Wilayah Provinsi Bali Nomor 16 Tahun 2009 dari sudut tujuan, pedoman dan kedudukan ternyata bahwa peran Rencana Tata Ruang Wilayah Provinsi dalam pembangunan demikian penting dan perlu bagi pembangunan Bali yang berkelanjutan khususnya dalam penyelamatan ruang dan lingkungannya yang akan berdampak pada kehidupan sosial budayanya.

Kabupaten Gianyar merupakan salah satu kabupaten yang memiliki daya tarik wisata yang cukup terkenal baik aspek fisik, sosial, budaya dan ekonomi (Febriyanti, Sudiarta, \& Suharta, 2018). Perkembangan daerah gianyar dipengaruhi oleh wisatanya. Pembangunan pariwisata dan perkembangan di daerah Gianyar tak lepas juga dari tekanan dampak dari lingkungan hidup.

Berkembangnya pariwisata tentunya dibarengi dengan berkembangya pelanggaran pemanfaatan ruang yang tidak sesuai dengan aturan tata ruang (Akib \& dkk, 2013), yang telah berlaku dan diterapkan pelaksanaan tata ruang yang tidak sesuai dengan aturan yang berlaku sehingga menghambat tujuan dari aturan tersebut.

Sungai merupakan salah satu sumber penopang kehidupan bagi masyarakat Bali, sungai dapat dimanfaatkan untuk berbagai kepentingan, baik untuk kepentingan kebudayaan, social, dan ekonomi. Hal ini menjadikan sungai sebagai sumber mata pencaharian bagi masyarakat Bali, salah satunya adalah Sungai Ayung. Pemandangan yang indah dipinggiran sungai dapat menarik wisata untuk berkunjung dan menarik pengusaha wisata untuk membangun fasilitas yang melanggar sempadan sungai.

Peraturan Daerah Kabupaten Gianyar Nomor 16 tahun 2012 tentang Rencana Tata Ruang Wilayah tahun 2012-2032 Pasal 1 ayat 51 yang menyatakan:

"Sempandan sungai adalah kawasan sepanjang tepi kiri dan kanan sungai, meliputi sungai alam dan buatan, kanal, dan saluran irigasi primer yang mempunyai manfaat penting untuk mempertahankan kelestarian fungsi sungai".

Jarak sempandan sungai juga di atur dalam Peraturan Daerah Nomor 16 tahun 2012 tentang Rencana Tata Ruang Wilayah Kabupaten Gianyar pada Pasal 37 ayat 2 menyatakan bahwa jarak sempadan sungai dalam perkotaan dan perdesaan.

Setiap penggunaan sempadan sungai harus sesuai dengan peruntukannya dan bangunan yang didirikan dipinggiran sungai harus sesuai dengan peraturan yang berlaku harus disertai dnegan izin pemerintah setempat. Dilihat dari realitanya masih ada bangunan di pinggiran Sungai Ayung yang melanggar jarak minimal sempadan sungai. Pelanggaran terhadap jarak sempadan sungai tersebut jika dibiarkan akan menimbulkan masalah yang lebih besar jika tidak ada kesadaran dari masyarakat ataupun tindakan tegas dari pemerintah.

Dilihat dari realita yang ada bahwa masih banyak bangunan yang berada di dalam sempadan sungai serta telah dikeluarkannya Peraturan Daerah kabupaten Gianyar maka diperlukan upaya yang tegas dari pemerintah untuk mengimplementasikan Perda tersebut agar perlindungan hukum terhadap daerah sempadan sungai dapat terwujud serta dimanfaatkan sebagaimana mestinya menurut peraturan yang ada.

Perlunya pengendalian pemanfaatan ruang untuk mengurangi dampak negatif tentunya harus disesuaikan dengan rencana tata ruang dan dapat diIakukan meIalui tata ruang penepatan zonasi, perizinan, pemberian intensif dan disintensif (Jazuli, 2017). Berdasarkan latar belakang tersebut, beranjak dari Pasal 1 ayat 51 Peraturan Daerah Kabupaten Gianyar Nomor 16 Tahun 2012 tentang RTRW Kabupaten Gianyar, penelitian ini bertujuan untuk menganalisis pengaturan pembangunan fasilitas pariwisata sempadan sungai dan mengetahui Pelaksanaan Peraturan Daerah Nomor 16 Tahun 2012 Tentang Rencana Tata Ruang Wilayah Kabupaten Gianyar dalam pembangunan fasilitas pariwisata. 


\section{METODE PENELITIAN}

Metode penelitian yang dipergunakan dalam penelitian ini yaitu penelitian hukum empiris (Soekanto \& Mamudji, 2003). Metode penelitian hukum yang menggunakan fakta empiris yang ada didalam masyarakat yang didapat dari wawancara maupun prilaku nyata yang dilakukan melalui pengatam secara langsung. Penelitian ini dilakukan berlokasi di Banjar Kedewatan Anyar, Desa kedewatan, Kecamatan Ubud, Kabupaten Gianyar. Sumber data yang dipergunakan dalam penelitian ini yaitu sumber yang diperoleh dari narasumber yang paling utama, dalam hal ini adalah wawancara langsung dengan kepala bidang Penataan Ruang Kabupaten Gianyar. Data dapat diperoleh dengan melalukan wawancara langsung sedangkan data hukum sekunder yang digunakan dari Undang-Undang Republik Indonesia Nomor 26 Tahun 2007 Tentang Penataan Ruang dan bahan hukum lain yang berkaitan dengan penelitian ini.

\section{HASIL DAN PEMBAHASAN}

\section{Pengaturan Pembangunan Fasilitas Pariwisata Sempadan Sungai}

Pada awal pemikiran tentang pembangunan sering ditemukan adanya pemikiran yang mengidentikan pembangunan dengan perkembangan, Tentunya pembangunan bertujuan memberikan perubahan dan kesejahteraan kepada seluruh umat manusia serta mencakup semua kebutuhanya. Perlunya mempertimbangkan dan merencanakan suatu bangunan, agar disaat membangun dapat memenuhi ciriciri bangunan. Ditambah dengan bangunan yang memperdulikan lingkungan disekitarnya. Perencanaan harus dijalankan sesuai prosedur, pentingnya bangunan yang menitik beratkan kelangsungan lingkungan hidup, dengan ciri-ciri sebagai berikut:

1. Mencerminkan dalam pemerataan dan keadilan;

2. Menghargai keanekaragaman hayati;

3. Menggunakan pandangan jangka panjang untuk merencanakan pengelolaan dan pemanfaatan dari sumber daya.

Pembangunan sendiri dapat berupa pembangunan secara nasional (Suparto, 2019) maupun daerah. Salah satu pengembangan pembangunan daerah adalah usaha di sektor pariwisata, salah satu daerah pariwisata yang terkenal di Indonesia yaitu Bali. Bali merupakan salah satu primadona pariwisata di Indonesia yang sudah dikenal di seluruh dunia. Dalam pembangunan-pembangunan fasilitas penunjang pariwisata, dapat dilihat dari sudut hukum tata ruang yang tunduk dengan berbagai asas. Pembangunan fasilitas penunjang pariwisata berupa hotel, villa, home stay dan masih banyak lagi yang lainnya dalam penyelenggaraanya mengacu pada Undang-Undang Nomor 26 tahun 2007 Tentang Perencanaan Ruang Pasal 6 Ayat 1 yang menyebutkan penataan yang mempertimbangkan kondisi fisik wilayah, Potensi sumber daya alam, sumber daya manusia, dan sumber daya buatan dan Geostrategi, geopolitik, dan geoekonomi (Yuntho, Munandar, \& Isa, 2013). Dalam pembangunan hotel dan villa di daerah Ubud Gianyar haruslah lebih memperhatikan aturan terkait dengan Geostrategi, geopolitik, dan geoekonomi mengingat permasalahan yang terjadi yaitu masih banyaknya bangunan- bangunan tersebut yang melanggar ketentuan terkait dengan lingkungan hidup yaitu melanggar garis sempadan sungai. Ini sudah terbukti dengan dibangunnya beragam fasilitas pariwisata di sepanjang Sungai Ayung.

Dalam Pemerintah Nomor 26 Tahun 2008 Tentang Rencana Tata Ruang Wilayah Nasional jelas disebutkan bahwa penataan ruang wilayah nasional salah satunya untuk meminimalisir perubahan fisik lingkungan yang dapat merusak dan menhilangkan fungsi juga kepentingan pembangunan mengarahkan alih fungsi tanah (Sumardjono, 2001), dari aspek penggunaan dan pemanfaatanya, hak atas tanah dapat digunakan untuk kepentingan mendirikan bangunan, misalnya perumahan, pertokoan, perkantoran, pabrik, rumah sakit dan hotel (Santoso, 2010).

\section{Pelaksanaan Peraturan Daerah Nomor 16 Tahun 2012 tentang Rencana Tata Ruang Wilayah Kabupaten Gianyar Dalam Pembangunan Fasilitas Pariwisata}

Pemerintah Provinsi Bali termasuk salah satu dari sepuluh provinsi di Indonesia yang sudah merevisi perda tata ruangnya disesuaikan dengan UU No. 26 Tahun 2007 (Sudiarta, 2011). Berbicara mengenai peraturan tentunya peraturan memiliki tujuan yang baik dan mulia yang ingin mensejahterakan dan memberikan ketertiban bagi seluruh masyarakat. Adapun pengertian aturan itu sendiri adalah sekumpulan norma- norma yang berlaku, baik dibuat secara tertulis maupun tidak tertulis yang dimana norma tersebut dibuat oleh penguasa yang berwenang yang diberlakukan kepada seluruh 
masyarakat yang mana apabila melanggar akan dikenakan sanksi pidana maupun administratif. Peraturan yang ada dan berlaku dimasyarakat dalam penerapanya masih adanya sistem yang kosong, dikarenakan tidak adanya jalinan pihak yang membuat sistem dan yang menerapkan sistem pemerintahan Negara (Asshiddiqie, 2014). Selain dari faktor pemerintahan peraturan yang telah ada dan telah diberlakukan di suatu negara tentunya tidak selamanya aturan itu akan terus berjalan sempurna, namun masih ada orang-orang yang melanggar aturan yang sangat jelas menjelaskan mengenai aturan dan larangan agar seseorang tidak menyimpang seperti halnya pelaksanaan peraturan daerah tata ruang wilayah di kabupaten gianyar.

Pelaksanaan peraturan daerah nomor 16 tahun 2012 tentang rencana tata ruang wilayah kabupaten gianyar dalam membangun berbagai fasilitas tentunya memiliki tujuan yang mana tujuan tersebut agar membangun bangunan yang memiliki wujud struktur ruang dan hubungan fungsional yang telah di sesuaikan didalam peraturan. Peraturan tersebut sudah berjalan sesuai aturan yang sudah ada namun tentunya masih ada sedikit yang melanggar membangun bangunan dipinggiran sungai. Didalam peraturan daerah kabupaten gianyar nomor 16 tahun 2012 tentang rencana tata ruang wilayah yang termuat didalam pasal 1 ayat 51 yang berbunyi :

"Sempadan sungai adalah kawasan sepanjang tepi kiri dan kanan sungai, meliputi sungai alam dan buatan, kanal, dan saluran irigasi primer yang mempunyai manfaat penting untuk mempertahankan kelestarian fungsi sungai"

Kawasan sungai alam maupun buatan, baik ditepi kiri maupun kanan memiliki manfaat yang penting guna mempertahankan kelestarian dari fungsi sungai itu sendiri, namun didalam pelaksanaanya masih terdapat beberapa bangunan-bangunan yang dibangun dipinggiran sungai yang tidak sesuai aturan dari jarak sempadan sungai itu sendiri khususnya di sungai ayung. Pada Pasal 37 ayat 2 huruf b yang menyatakan bahwa jarak sempadan sungai meliputi:

"Pada kawasan perdesaan: 5 meter sungai bertanggul, 10 meter untuk sungai berkedalaman lebih dari 3 meter, 15 meter untuk sungai berkedalaman 3 sampai 20 meter, dan 30 meter untuk sungai berkedalaman lebih dari 20 meter".

Rencana tata ruang wilayah kabupaten gianyar khususnya dipinggiran sungai ayun masih ada beberapa hotel dan villa yang terdapat melanggar dari aturan jarak membangun dari sempadan sungai yang telah di sebutkan diatas, hotel tersebut dibangun dipinggiran sungai ayung yang berjarak kurang lebih 2 meter dari bibir sungai, sungai ayung sendiri memiliki kedalaman lebih dari 3 meter yang tentunya aturan untuk membangun bangunan harus berjarak 10 meter dari pinggiran sungai.

Hampir semua peraturan tentunya bertujuan untuk menciptakan kedamaian dan ketertiban bagi seluruh masyarakat, namun tidak menutup kemungkinan peraturan tersebut dapat berjalan dengan maksimal, namun masih saja ada yang melanggar aturan tersebut baik itu kurang pahamnya akan aturan yang ada atau memang dengan sengaja melanggar guna kepentingan pribadinya. Dapat dikatakan bahwa ada tiga faktor yang sering terjadi akibat pelanggaran yang dilakukan terkait aturan pembangunan dikawasan pinggiran sungai ayung Kabupaten Gianyar tentunya aturan tersebut harus tetap ditegakan dan dijalankan guna demi keselamatan juga dikarenakan Kawasan yang dibangun yang telah diatur dan diberikan jarak tentunya bertujuan agar terhindar dari terjadinya bencana yang sewaktu-waktu dapat terjadi bagi bangunan yang berada dikawasan pinggiran sungai.

Faktor-faktor yang menjadi penghambat bagi seseorang untuk Melanggar Peraturan Daerah Nomor 16 Tahun 2012 Tentang Rencana Tata Ruang Wilayah Kabupaten Gianyar pasal 37 ayat 2 huruf $\mathrm{b}$ tentang jarak sempadan sungai menurut kepala bidang Penataan Ruang Gusti Putu Arta Mustika menjelaskan bahwa:

1. Memiliki lahan tanah yang sedikit sehingga mengambil batas dari jarak sempadan sungai yang telah ditetapkan;

2. Membangun bangunan yang akan dibangun terlebih dahulu kemudian membuat surat ijin mendirikan bangunan; dan

3. Pertimbangan dikarenakan tanah yang dibangun adalah milik orang itu sendiri dan masih warga asli gianyar itu sendiri sehingga merasa canggung untuk memberikan teguran.

Dapat dikatakan bahwa ada tiga faktor penghambat yang sering terjadi akibat pelanggaran yang dilakukan terkait aturan pembangunan dikawasan pinggiran sungai ayung Kabupaten Gianyar. Menurut Masyarakat setempat I Wayan Ary Gunawan mejelaskan bahwa, aturan tersebut harus tetap ditegakan dan dijalankan guna demi keselamatan juga dikarenakan Kawasan yang dibangun yang 
telah diatur dan diberikan jarak tentunya bertujuan agar terhindar dari terjadinya bencana yang sewaktu-waktu dapat terjadi bagi bangunan yang berada dikawasan pinggiran sungai. Menurut Masyarakat setempat I Gede Tunas Sukada mejelaskan bahwa, aturan tersebut ada dan untuk dijalankan serta ditaati, bukan untuk dilanggar. Karena aturan yang bisa saya definisikan adalah untuk memberikan rasa aman dan ketertiban didalam masyarakat guna kehidupan yang damai dan tentram.

Kebijakan yang diberikan oleh orang yang terbukti melanggar aturan tersebut menurut kepala bidang Penataan Ruang Gusti Putu Arta Mustika menjelaskan bahwa:

1. Surat peringatan pertama

Surat yang diberikan pertama kali bila terbukti melanggar aturan penataan ruang saat mendirikan bangunan yaitu diberikan teguran awal untuk mengecek kembali teknis bangunan gedung yang telah dibuat sebelumnya.

2. Surat peringatan kedua

Surat yang diberikan untuk kedua kali bila terbukti masih melanggar aturan penataan ruang saat mendirikan bangunan yaitu diberikan teguran kedua kalinya untuk segera mengecek kembali dan pemberhentian sementara bangunan yang sedang dalam masa membangun.

3. Surat peringatan ketiga.

Surat yang diberikan untuk ketiga kali bila terbukti melanggar aturan penataan ruang saat mendirikan bangunan yaitu diberikan teguran yang terakhir untuk segera melakukan penghentian pembangunan agar tidak melanjutkan kembali pembangunan yang dilakukan namun jika masih tetap melanggar dapat dikenakan pencabutan surat ijin mendirikan bangunan dan dapat dilakukan pembongkaran paksa.

Setiap pelanggaran tentunya akan mendapatkan hukuman atau sanksi yang diterima, sama halnya dengan pelanggar aturan sempadan sungai yang membangun bangunan di pinggiran sungai yang tidak sesuai jarak yang telah diatur didalam aturan tersebut. Sanksi tersebut diberikan bukan semata-mata hanya dijatuhkan saja, namun sanksi tersebut dijatuhkan untuk memberikan efek jera kepada pelanggar agar tidak melanggar kembali aturan yang telah ada, dan tentunya dengan tujuan untuk kebaikan pelanggar itu sendiri bahwa sangat beresiko membangun bangunan disekitar pinggiran sungai yang dapat mengakibatkan terkena banjir dan rawan tanah longsor yang dapat memberikan kerugian kepada orang yang membangunanya. Aturan bukan semata-mata hanya memuat larangan dan sanksi saja, namun aturan tersebut ada dan diberlakukan untuk kepentingan seluruh masyarakat dan memberikan jaminan keamanan sehingga terhindar dari hal-hal yang tidak diinginkan.

\section{SIMPULAN DAN SARAN}

Berdasarkan uraian dan pembahasan yang telah dipaparkan di atas, maka dapat ditarik kesimpulan bahwa pengaturan pembangunan fasilitas pariwisata sempadan sungai dalam hukum positif di Indonesia termuat dalam Undang-Undang Nomor 26 tahun 2007 Tentang Perencanaan Ruang. Selain dalam Undang-Undang tersebut sempadan sungai juga di atur dalam Peraturan Pemerintah Nomor 26 Tahun 2008 Tentang Rencana Tata Ruang Wilayah Nasional. Demi adanya keselarasan terhadap Perundang-Undangan yang sudah ada, maka Daerah Kabupaten Gianyar juga membuat Peraturan Daerah Kabupaten Gianyar Nomor 16 tahun 2012 tentang Rencana Tata Ruang Wilayah tahun 20122032 mengatur tentang sempadan sungai pada Pasal 37 Ayat 2 menjelaskan lebih jelan mengenai pembangunan yang dilakukan di dekat Kawasan sungai yang telah diberikan aturan pembangunan di sungai pedesaan. Dari Pelaksanaan Peraturan Daerah Nomor 16 Tahun 2012 Tentang Rencana Tata Ruang Wilayah Kabupaten Gianyar dalam pembangunan fasilitas pariwisata sudah berjalan dengan baik tetapi dapat dilihat melalui kalkulasi yang dihitung oleh Kapala Bidang Penataan Ruang bahwa telah terlaksana sebesar $89 \%$ sudah berjalan dengan baik dan $11 \%$ masih adanya penyimpangan. Kebijakan yang diberikan oleh orang yang terbukti melanggar aturan tersebut akan diberikan Surat Peringatan sebanyak 3 (tiga) kali dan jika masih melanggar maka akan diberikan sanksi administrative sesuai dengan keberlakuan Perundang-Undangan.

Adapun saran yang dapat diberikan oleh penulis yaitu Untuk para pengusaha yang membangun fasilitas-fasilitas pariwisata sebaiknya lebih diperhatikan kembali aturan-aturan hukum yang tengah berlaku mengingat dalam peraturan tersebut terdapat sanksi yang akan menjerat jika diketahui melanggar. Selain untuk para pengusaha yang membangun, keterlibatan masyarakat sekitar juga sangat diperlukan untuk berperan aktif mengawasi pembangunan-pembangunan di wilayahnya agar pembangunan tersebut tidak merusak lingkungan dan ekosistem alam sekitar. Sedangkan Untuk 
Pemerintah agar lebih tegas dalam pengawasan terhadap pembangunan-pembangunan yang terjadi mengingat perlunya menjaga lingkunga dan ekosistem hidup yang terdapat pada Daerah seputaran sepadan sungai.

\section{DAFTAR PUSTAKA}

Akib, M., \& Dkk. (2013). Hukum Penataan Ruang. Bandar Lampung: PKKPUU FH UNILA.

Asshiddiqie, J. (2014). Pengantar Ilmu Hukum Tata Negara. Jakarta: Rajawali Pers.

Febriyanti, I. A. A. C., Sudiarta, I. K., \& Suharta, I. N. (2018). Pengendalian Pemanfaatan Ruang Pada Kawasan Sempadan Sungai Di Kabupaten Gianyar. Kertha Negara: Journal Ilmu Hukum, 6(3).

Jazuli, A. (2017). Penegakan Hukum Penataan Ruang Dalam Rangka Mewujudkan Pembangunan Berkelanjutan. Jurnal Rechts Vinding, 6(2).

Santoso, U. (2010). Pendaftaran dan Peralihan Hak Atas Tanah (I). Jakarta: Kencana.

Soekanto, S., \& Mamudji, S. (2003). Penelitian Hukum Normatif: Suatu Tinjauan Singkat. Jakarta: PT. RajaGrafindo Persada.

Sudiarta, I. K. (2011). Penetapan Kawasan Tempat Suci dan Kawasan Pariwisata Dalam Penataan Ruang di Bali. Masalah-Masalah Hukum, 40(1).

Sumardjono, M. S. W. (2001). Kebijakan Pertanahan antar Regulasi dan Implementasi. Jakarta: PT. Kompas Media Nusantara.

Suparto. (2019). Pembentukan Peraturan Daerah Tentang Rencana Tata Ruang Wilayah (RTRW) Provinsi Riau: Dinamika dan Permasalahannya. JURNAL SELAT, 6(2).

Yuntho, E., Munandar, A., \& Isa, M. (2013). Public Review Rancangan Peraturan DaerahRencana Tata Ruang WilayahProvinsi Kalimantan Barat. Lembaga Gemawan - Indonesia Corruption Watch. 